\title{
KOMUNIKASI PELAKSANAAN PROGRAM KESETARAAN PAKET C DI PUSAT KEGIATAN BELAJAR MASYARAKAT (PKBM) TIARA DEZZY SAMARINDA
}

\author{
Hepy Triwinarti \\ Universitas Mulawarman \\ pos-el: hepytriwinarti.triwinarti51@gmail.com
}

\begin{abstract}
ABSTRAK
Tujuan dalam penelitian ini adalah menganalisis mengenai komunikasi pelaksanaan program kesetaraan paket C di Pusat Kegiatan Belajar Masyarakat (PKBM) Tiara Dezzy Samarinda. Penelitian ini menggunakan penelitian kualitatif yang lebih berdasarkan pada filsafat fenomenologis yang mengutamakan penghayatan. Subjek penelitian ini adalah Ketua PKBM, staff pengelola dan tutor, serta warga belajar. Teknik pengumpulan data berupa observasi, wawancara, dan studi dokumentasi. Teknik analisis data yang digunakan adalah analisis model interaktif Miles dan Huberman yang dilakukan melalui tiga alur kegiatan yaitu reduksi data, penyajian data, dan penarikan kesimpulan. Hasil penelitian diperoleh data yaitu: komunikasi dalam pelaksanaan program paket $\mathrm{C}$ sudah berjalan efektif. Hal ini terjadi karena komunikasi yang terjalin antara Kepala PKBM dengan staf dan tutor serta warga belajar. Di semua aspek sudah terjalin yang termasuk dari aspek langsung, tegas, ramah dan bersahabat, kejelasan, ketepatan, konteks, alur, dan budaya.
\end{abstract}

\section{Kata kunci : Komunikasi, Kesetaraan paket C, PKBM}

\begin{abstract}
The purpose of this study was to analyze the communication of the implementation of the package $C$ equivalency program at the Tiara Dezzy Samarinda Community Learning Activity Center (PKBM). This study uses qualitative research which is more based on a phenomenological philosophy that prioritizes appreciation. The subjects of this study were the Chairperson of the PKBM, management staff and tutors, as well as learning citizens. The data collection techniques were observation, interview, and documentation study. The data analysis technique used was the interactive model analysis by Miles and Huberman, which was carried out through three activity lines, namely data reduction, data presentation, and conclusion drawing. The results of the study obtained data, namely: communication in the implementation of the package $C$ program has been running effectively. This happens because of the communication established between the Head of PKBM and the staff and tutors as well as the learning community. All aspects have been established, including direct, firm, friendly and welcoming, clarity, accuracy, context, flow, and culture.
\end{abstract}

Keywords: Communication, Equality of package C, PKBM

\section{PENDAHULUAN}

Pendidikan pada hakikatnya adalah usaha sadar untuk mengembangkan kepribadian dengan kemampuan di dalam dan di luar sekolah dan berlangsung seumur hidup dan dilaksanakan dalam lingkungan keluarga, sekolah, dan masyarakat. UU Sisdiknas No.20/2003 mengemukakan bahwa pada pedoman pembelajaran pendidikan kesetaraan Paket A, Paket B dan Paket C disebutkan bahwa program paket c adalah program pendidikan yang pada jalur pendidikan nonformal yang dapat diikuti oleh warga belajar yang ingin menyelesaikan pendidikan setara SMA/MA. Lulusan program paket $\mathrm{C}$ berhak mendapat ijazah dan diakui setara dengan ijazah SMA/MA.

Dalam pelaksanaan Program Paket C komunikasi yang dilakukan adalah komunikasi antara Ketua PKBM kepada staf 
dan para tutor, kemudian informasi dikomunikasikan kepada para warga belajar Paket $\mathrm{C}$ untuk mengetahui informasi tentang pelaksanaan Program Paket C. Hanya saja jumlah warga belajar pada saat mendaftar dan pada saat lulusnya berbeda dikarenakan warga belajar belum mengetahui pentingnya mengikuti Program Paket C. Kenyataannya banyak dari warga belajar hanya termotivasi dengan ijazah, bukan dengan ilmu yang diberikan pada program Paket $\mathrm{C}$ yang diselenggarakan oleh PKBM. Ada pula warga belajar yang tidak dapat melanjutkan sekolah banyak memilih untuk bekerja baik di rumah dan merantau untuk membantu orang tua daripada melanjutkan sekolah melalui jalur keaksaraan.

Dari hasil tersebut menunjukkan minat belajar lulusan SMP/Program Paket B ke Program Paket C relatif Rendah. Artinya, respons masyarakat belum menggembirakan. Penyebabnya adalah masih terbatasnya komunikasi informasi mengenai Program Paket $\mathrm{C}$ dan masyarakat belum sepenuhnya mengetahui program di dalamnya seperti apa, sehingga perlu adanya sosialisasi yang harus di komunikasikan kepada masyarakat.

Untuk mengatasi permasalahan ini perlu adanya komunikasi dalam proses pelaksanaan Program Paket C, karena prosesnya dapat tercipta komunikasi yang harmonis dan terbuka bagi ketua PKBM, pengelola atau tutor maupun warga belajar sendiri. Komunikasi juga dapat berperan dalam mencapai keberhasilan pelaksanaan Program Paket C sebab aspek komunikasi yang dilakukan pada saat proses pelaksanaan akan membangkitkan motivasi warga belajar agar selalu aktif belajar.

Komunikasi yang dilakukan hendaknya sesuai dalam menyampaikan semua informasi-informasi yang penting yang berkaitan dalam pelaksanaan Program Paket C. Jika dilihat dari aspek komunikasi kita dapat melihat bahwa komunikasi yang dilakukan pada program ini adalah komunikasi yang pasif tampak pada masalah yang timbul ketika ada kesenjangan antara ketua PKBM, staf dan tutor maupun warga belajar sendiri.

Permasalahan kualitas pendidikan dengan indikator paling nyata dari rendahnya kualitas pendidikan di Indonesia adalah rendahnya perolehan hasil ujian belajar warga belajar. Hasil yang diharapkan adalah supaya keseluruhan program yang akan dilaksanakan tetap mengacu pada pola yang sistematis, terpadu, dan berkelanjutan untuk menu kepada produktivitas sebagai hasil dari pembelajaran ini menghasilkan, meningkatkan sumber daya manusia (SDM) yang berkualitas, mempunyai keterampilan yang relevan yang berorientasi dalam kehidupan sehari-hari, terselenggaranya program pembelajaran sesuai dengan rencana dan tidak ada yang putus sekolah. Sehingga angka persentase putus sekolah paket $\mathrm{C}$ setara SMA dapat menurun. Selanjutnya peneliti tertarik untuk meneliti tentang "Komunikasi Pelaksanaan Program Kesetaraan Paket C Di Pusat Kegiatan Belajar Masyarakat (PKBM) Tiara Dezzy Samarinda."

Marwansyah mengemukakan bahwa komunikasi adalah pertukaran pesan antar manusia dengan tujuan pemahaman yang sama. Goyer (Eko Harry Susanto, 2010:13) menyebutkan bahwa komunikasi dinilai efektif, bila rangsangan yang disampaikan dan dimaksud oleh pengirimnya atau sumber pesan, sejalan dengan rangsangan yang ditangkap dan dipahami oleh penerima pesan.

Robbins (2003:78) mengatakan bahwa suatu komunikasi dikatakan efektif apabila mengandung aspek-aspek sebagai berikut : 1) Langsung adalah informasi yang disampaikan secara langsung atau tidak 
ragu. 2) Assertive adalah penyampaian informasi tidak ada perasaan takut untuk menyampaikan apa yang diinginkan dan menyampaikan pertanyaan mengapa. 3) Ramah dan bersahabat adalah informasi yang disampaikan sebaiknya dibarengi dengan sikap dan air muka yang ramah dan ada kesan bersahabat. 4) Kejelasan adalah bahwa bahasa maupun informasi yang disampaikan harus jelas atau mudah dimengerti. 5) Ketepatan adalah bahasa yang digunakan harus sesuai dengan apa yang sesungguhnya ingin disampaikan. 6) Konteks adalah bahasa dan informasi yang disampaikan harus sesuai degan keadaan dan lingkungan di mana komunikasi itu terjadi. 7) Alur adalah komunikasi yang efektif akan tercapai apabila dalam penyampaiannya informasi tersebut disampaikan dengan alur bahasa secara runtut dan terjadi dua arah. 8) Budaya adalah aspek ini tidak saja menyangkut bahasa dan informasi, tetapi juga menyangkut tata krama dan etika.

UU Sisdiknas No.20/2003 menyatakan Pendidikan kesetaraan adalah program pendidikan non formal yang diselenggarakan pendidikan umum setara SD/MI, SMP/MTS, dan SMA/MA yang mencakup program paket $\mathrm{A}$, paket $\mathrm{B}$, dan paket C. Program Paket C setara SMA adalah program pendidikan lanjutan dari Paket B setara SLTP. Pusat Kegiatan Belajar Masyarakat (PKBM) sebagai wadah/tempat pendidikan atau pemberdayaan yang mencerminkan keswadayaan masyarakat.

\section{METODE PENELITIAN}

Penelitian ini menggunakan penelitian kualitatif yang lebih berdasarkan pada filsafat fenomenologis yang mengutamakan penghayatan. Moleong (2013:3) mengemukakan bahwa pendekatan kualitatif ini dapat dipandang sebagai prosedur penelitian yang menghasilkan data deskriptif berupa katakata tertulis atau lisan dari orang-orang dan perilaku yang dapat diamati. Penelitian kualitatif dapat dilakukan untuk memahami berbagai fenomena perilaku ketua PKBM, staf dan tutor serta warga belajar dalam komunikasi pelaksanaan program kesetaraan paket $\mathrm{C}$.

Sesuai dengan judul yaitu Aspek Komunikasi Pelaksanaan Program Kesetaraan Paket C di Pusat Kegiatan Belajar Masyarakat (PKBM) Tiara Dezzy Samarinda, terkait dengan aspek, Langsung, Assertive, Ramah dan Bersahabat, Kejelasan, Ketepatan, Konteks, Alur, Budaya. Sumber data dalam penelitian ini dibedakan atas sumber data primer dan sekunder. Sumber data primer orang-orang yang terlibat dalam pelaksanaan program paket $\mathrm{C}$ di PKBM Tiara Dezzy yaitu Ketua PKBM, staf dan tutor serta warga belajar. Data sekunder di dapat dari dokumen dan berbagai sumber pelaksanaan paket $\mathrm{C}$ seperti Ketua PKBM, staf dan tutor serta warga belajar paket $\mathrm{C}$.

Penelitian ini juga perlu memilih teknik dan alat pengumpulan data yang relevan, yaitu observasi, wawancara, dan studi dokumentasi. Husein (2009 : 51) mengemukakan bahwa teknik ini menuntut adanya pengamatan dari peneliti baik secara langsung ataupun tidak langsung terhadap objek penelitiannya. Moleong (2011 : 186) mengemukakan bahwa wawancara adalah percakapan dilakukan oleh dua orang pihak, yaitu pewawancara yang mengajukan pertanyaan dan yang diwawancarai yang memberikan jawaban atas pertanyaan tersebut. Bungin (2012 : 123) mengemukakan bahwa dokumenter adalah 
metode yang digunakan untuk menelusuri data historis yang sejumlah besar fakta dan data sosial tersimpan dalam bahan yang berbentuk dokumentasi. Teknik analisis data yang digunakan adalah analisis model interaktif Miles dan Huberman yang dilakukan melalui tiga alur kegiatan yaitu reduksi data, penyajian data, dan penarikan kesimpulan

\section{HASIL DAN PEMBAHASAN}

\section{Aspek Langsung}

Pada tahap ini terlihat bahwa komunikasi dalam penyampaian informasi yang dilakukan secara langsung antara Ketua PKBM Tiara Dezzy dengan staf pengelola/tutor dan diteruskan kepada warga belajar. Ketua PKBM mempunyai banyak sekali pengetahuan di bidangnya sehingga dapat menuntun anggotanya. Apabila ada anggota PKBM tidak mengerti, dapat langsung bertanya tanpa perlu mencari informasi lagi dan di jelaskan secara rinci langsung dari ketua PKBM. Menanyakan informasi yang sesuai dengan apa yang ingin di sampaikan juga merupakan dari salah satu aspek komunikasi yang lain yaitu aspek ketepatan yang mengandung arti bahasa yang digunakan harus sesuai dengan apa yang sesungguhnya diinginkan.

Mengadakan rapat pertemuan sudah direncanakan terlebih dahulu agar tidak ada terjadi perubahan keadaan saat penyampaian informasi berlangsung dan pemberitahuan apa yang akan dibahas disampaikan melalui media sosial yaitu WA (WhatsApp). Dari warga belajar mudah memahami penjelasan secara jelas dan baik dari informasi yang diberikan oleh tutor saat di kelas. Dari kegiatan di atas dapat dikatakan bahwa aspek langsung informasi sudah di sampaikan secara langsung dari Ketua PKBM Tiara
Dezzy ke staff pengelola dan tutor dan di teruskan lagi kepada warga belajar. Untuk tingkat pengetahuan Ketua PKBM Tiara Dezzy dapat menjadi faktor utama dalam komunikasi sehingga apa yang ingin disampaikan bisa dengan mudah apabila ia memiliki pengetahuan yang luas.

\section{Aspek tegas}

Pada tahap ini terlihat bahwa tidak ada perasaan takut dalam penyampaian informasi terutama tentang pelaksanaan program paket C di PKBM Tiara Dezzy karena informasi yang di sampaikan sudah sesuai dengan apa yang sudah direncanakan dan seharusnya diberitahukan. Setiap PKBM selalu mempunyai tim yang bisa di ajak kerja sama baik di dalamnya ada Ketua PKBM dan Anggota PKBM satu sama lain saling terhubung seperti layaknya keluarga sendiri. Ketua PKBM menyampaikan informasi secara transparan terutama dalam hal pendanaan yang didapat berasal dari pengajuan dana yang disetujui dari BOP KEMENDIKBUD. Warga Belajar juga diberitahukan informasi mengenai dana tersebut secara transparan sehingga mereka mengetahui dana yang dikeluarkan sesuai dengan kebutuhan mereka secara gratis melalui program ini.

Dari kegiatan di atas dapat dikatakan bahwa aspek tegas sudah dilaksanakan dengan baik dan dapat dilihat betapa pentingnya sikap transparan dalam suatu organisasi yaitu PKBM di mana dalam penyampaian informasi tidak ada rasa takut sehingga bisa saling berhubungan satu sama lain serta antar anggota PKBM maupun warga belajarnya. Komunikasi juga bisa menjadi lebih efektif apabila isi informasi mengandung sesuatu yang berarti dan penting untuk diketahui si penerima informasi. 


\section{Aspek Ramah dan Bersahabat.}

Keramahtamahan dan kesan yang bersahabat menjadi hal yang biasa dilakukan di PKBM Tiara Dezzy demi terciptanya suatu hubungan kekeluargaan sehingga dapat saling kerja sama satu tim yang kompak. Komunikasi yang dijalani dilakukan secara kekeluargaan atau tidak formal sehingga tidak memiliki batasan dan lebih leluasa dalam bertanya tentang hal yang tidak dimengerti. Baik anggota maupun Ketua PKBM sudah mengenal satu sama lain dikarenakan sudah lama bekerja di PKBM Tiara Dezzy dan tanpa membeda-bedakan mereka dalam hal apapun. Penjelasan informasi dari tutor dengan kesan yang ramah dan bersahabat selalu dirasakan oleh warga belajar baik dalam suasana pembelajaran maupun di luar pembelajaran, baik secara lisan maupun melalui media misanya LCD. Jika ada perubahan informasi terbaru dari dinas pendidikan mengenai pelaksanaan program paket $\mathrm{C}$ tentang kurikulum yang terbaru biasanya akan selalu disampaikan saat rapat pertemuan.

Dari kegiatan di atas dapat dikatakan bahwa aspek ramah dan bersahabat sudah dilaksanakan dengan baik dan dapat dilihat betapa kita menyadari, betapa hubungan yang hangat, ramah sangat dipengaruhi kemampuan seseorang untuk berkomunikasi dengan orang lain. Proses komunikasi yang kita lakukan tiap hari berfungsi untuk memupuk dan memelihara hubungan kita dengan lingkungan.

\section{Aspek Kejelasan}

Aspek kejelasan adalah bahwa bahasa maupun informasi yang disampaikan harus jelas atau mudah dimengerti. Kebanyakan dari mereka yang menjadi anggota PKBM sudah banyak mengetahui tentang bagaimana standar pengelolaan paket A, B dan C karena sudah lama mengajar dan bekerja di PKBM Tiara Dezzy. Terkecuali jika ada pengarahan dari informasi yang terbaru seperti perubahan KTSP menjadi Tematik K13 maka barulah mereka mengalami perubahan rencana atau perlu diadakan rapat kembali. Rapat yang dilakukan tidak dalam suasana yang tegang tapi bisa dilakukan dengan santai sambil minum kopi bersama menciptakan hubungan kekeluargaan. Ketua PKBM untuk menyampaikan komunikasi haruslah dijelaskan dengan jelas dan dengan bahasa yang sederhana untuk bisa dimengerti anggota PKBM.

Terkadang warga belajar PKBM Tiara Dezzy mengalami kesulitan dalam menerima informasi dikarenakan sebagian dari mereka pernah mengalami putus sekolah sehingga mereka kurang cepat dan tanggap dengan informasi yang diberikan. Maka seorang tutor dapat membantu warga belajarnya dengan memberi pengawasan atau sikap peduli serta mengarahkan secara perlahan-lahan kepada mereka sampai mereka dapat memahami informasi tersebut. Dalam hal ini, tingkat pemahaman seseorang berbeda-beda tergantung beberapa faktor, contohnya latar belakang pendidikan, usia, ataupun status sosial.

Dari kegiatan di atas dapat dikatakan bahwa aspek kejelasan sudah dilaksanakan dengan baik dan dapat dilihat Ketua PKBM maupun anggota PKBM sudah melaksanakan komunikasi dengan jelas dan memang harus siap memberikan pelayanan informasi baik dari segi pembelajaran, kegiatan yang dijalankan dan lain-lainnya yang pastinya ingin mencapai suatu keberhasilan dan tujuan yang diinginkan dalam pelaksanaan program terutama paket $\mathrm{C}$. 


\section{Aspek Ketepatan}

Aspek Ketepatan adalah bahasa yang digunakan harus sesuai dengan apa yang sesungguhnya ingin disampaikan. Percakapan sehari-hari yang berlangsung di PKBM Tiara Dezzy baik secara tidak resmi maupun resmi tetap memakai bahasa Indonesia dikarenakan anggota PKBMnya memiliki asal daerah/suku yang berbedabeda. Maka menggunakan bahasa Indonesia sebagai komunikasi sudah seharusnya dianggap suatu kewajaran bagi PKBM Tiara Dezzy.

Selain berbicara secara langsung kepada si penerima informasi, ada cara lain untuk berkomunikasi, yaitu menggunakan media. Penggunaan media sosial WA (whatsapp) di PKBM Tiara Dezzy lebih sering digunakan dari pada menggunakan telepon pribadi karena di rasa lebih efektif dan lebih hemat daripada menelepon 1 orang. Pertimbangan secara matang oleh ketua PKBM tentang pemilihan media yang sesuai dan tepat sasaran agar tidak terjadi komunikasi yang sia-sia.

Terkadang ada sharing konsultasi antara wali warga belajar (Orang Tua) dengan tutor mengenai perkembangan anak-anaknya di PKBM. Dari kegiatan di atas dapat dikatakan bahwa aspek ketepatan sudah dilaksanakan dengan baik dan dapat dilihat sudah seharusnya penggunaan bahasa untuk komunikasi yang tepat adalah menggunakan Bahasa Indonesia. Bahasa Indonesia masih di gunakan secara aktif dalam interaksi sehari-hari oleh PKBM Tiara Dezzy.

\section{Aspek Konteks}

Aspek Konteks adalah bahasa dan informasi yang disampaikan harus sesuai dengan keadaan dan lingkungan di mana komunikasi itu terjadi. Dari segi bahasa yang dipakai di PKBM Tiara Dezzy sudah cukup sesuai karena selalu memakai bahasa yang mudah dimengerti yaitu bahasa Indonesia. Secara konteksnya apabila terjadi perubahan dalam rencana pelaksanaan program maka akan di berikan pemberitahuan atau arahan yang dilakukan melalui sosialisasi jauh-jauh hari agar kegiatan yang dijalankan terencana dengan baik. Perubahan yang terjadi disesuaikan mengikuti mengikuti petunjuk atau informasi yang di sampaikan dari pemberitahuan/arahan terbaru Ketua PKBM dan tugas yang diberikan menjadi tugas tambahan buat anggota PKBM serta diteruskan langsung ke warga belajar Paket C.

Dari kegiatan di atas dapat dikatakan bahwa aspek konteks sudah dilaksanakan dengan baik dan dapat dilihat proses komunikasi lebih mudah dipahami, apabila kita bisa memahami konteks yang terjadi dalam komunikasi. Dalam menyampaikan informasi yang baik harus memperhatikan situasi dan kondisi komunikasi berada, sehingga komunikasi dapat berjalan dengan baik.

\section{Aspek Alur}

Alur adalah komunikasi yang efektif akan tercapai apabila dalam penyampaiannya informasi tersebut disampaikan dengan alur bahasa secara runtut dan terjadi dua arah. Dipaparkan dengan beberapa nara sumber dan observasi yang dilakukan mengungkapkan bahwa dalam berorganisasi kita dituntut untuk dapat melakukan komunikasi yang baik antar sesama anggota agar prosesnya dapat terjadi umpan balik. Penyampaian informasi di PKBM terjadi dua arah atau lebih tepatnya terjadi umpan balik, di mana informasi yang disampaikan melalui media maupun pertemuan dilakukan secara runtut dan ada umpan balik dari anggota PKBMnya. 
Selain anggota PKBM dapat bertanya, mereka juga memberi masukan langsung kepada ketua PKBM sehingga apabila terjadi permasalahan dalam pelaksanaan dapat di selesaikan dengan baik secara kekeluargaan. Komunikasi dua arah dan umpan balik terjadi juga antara tutor dan warga belajarnya, info disampaikan langsung saat kapan dan di manapun agar mereka tidak ketinggalan informasi dalam mengikuti program yang dijalankan. Menurut warga belajar komunikasi yang efektif sangat diperlukan karena memudahkan mereka untuk bertanya jika mereka masih merasa kurang paham akan informasi sekaligus bisa meminta saran untuk menyelesaikan masalahnya.

Dari kegiatan di atas dapat dikatakan bahwa aspek Alur sudah dilaksanakan dengan baik dan dapat dilihat dari proses komunikasi yang terjadi di PKBM Tiara Dezzy pada dasarnya menjelaskan bagaimana komunikasi itu berlangsung melalui berbagai tahapan yang dilakukan secara terus-menerus, berubah-ubah, dan tidak ada hentinya dalam rangka penyampaian informasi. Komunikasi terus berlanjut tanpa henti sesuai dengan alurnya dalam penyampaian informasi.

\section{Aspek budaya}

Aspek budaya adalah aspek ini tidak saja menyangkut bahasa dan informasi, tetapi juga menyangkut tata krama dan etika. Dalam menyampaikan informasi, PKBM tiara Dezzy ini menggunakan bahasa yang santai namun selalu mengedepankan tata krama serta etika saat berkomunikasi. Walaupun dari segi umur, pendidikan, status mereka berbeda, mereka tetap saling menghargai dan menghormati tanpa perlu membedabedakan dalam berkomunikasi. Ketua PKBM Tiara Dezzy selalu menerapkan budaya 5S kepada setiap anggotanya baik itu kepada sesama anggota, antara bawahan dengan atasan, maupun dengan warga belajarnya. Ketua PKBM maupun Anggota PKBM selalu bersikap sopan santun, ramah-tamah, baik kepada warga belajar yang berkunjung ke PKBM Tiara Dezzy dengan tujuan agar warga belajar tersebut berminat dengan PKBMnya

Dari kegiatan di atas dapat dikatakan bahwa aspek budaya sudah dilaksanakan dengan baik dan dapat dilihat di PKBM Tiara Dezzy komunikasi tidak hanya sekedar pesan yang dikirim dari satu anggota ke anggota lain melalui satu atau lebih saluran.

\section{KESIMPULAN}

Hasil penelitian menunjukkan bahwa: 1) Aspek Langsung yaitu komunikasi dalam penyampaian informasi yang dilakukan secara langsung atau tidak raguragu antara Ketua PKBM Tiara Dezzy dengan staf dan tutor serta diteruskan kepada warga belajar. 2) Aspek tegas yaitu Ketua dan anggota PKBM menyampaikan informasi tidak ada perasaan takut dan secara transparan terutama dana yang didapat sebagai kunci utama untuk kelangsungan program. 3) Aspek ramah dan bersahabat yaitu keramahtamahan dan kesan yang bersahabat menjadi hal yang biasa dilakukan di PKBM Tiara Dezzy demi terciptanya suatu hubungan kekeluargaan dalam tim. 4) Aspek kejelasan, yaitu Ketua PKBM untuk menyampaikan komunikasi haruslah dijelaskan dengan jelas dan dengan bahasa yang sederhana untuk mudah dimengerti anggota PKBM. 5) Aspek Ketepatan yaitu bahasa Indonesia selalu di gunakan secara aktif dalam interaksi sehari-hari dikarenakan untuk memudahkan dalam berkomunikasi satu sama lain. 6) Aspek Konteks yaitu konteksnya apabila terjadi 
perubahan dalam rencana pelaksanaan program maka akan di adakan sosialisasi lebih dulu sebelum kegiatan dimulai. 7) Aspek Alur yaitu penyampaian informasi di PKBM terjadi dua arah atau umpan balik, di mana informasi yang disampaikan melalui media maupun pertemuan dilakukan secara runtut dan ada umpan balik dari anggota PKBMnya. 8) Aspek Budaya yaitu dalam menyampaikan informasi, PKBM tiara Dezzy menggunakan bahasa yang santai namun selalu mengedepankan tata krama serta etika saat berkomunikasi.

Beberapa saran yang dapat diberikan peneliti yaitu perlunya mempertahankan upaya yang dilakukan untuk mewujudkan komunikasi yang efektif dengan melatih kejujuran, rasa tanggung jawab dan transparansi. 2. Perlu meninjau kembali dan mengevaluasi diri terkait kegiatan atau ucapan yang beresiko terjadinya penafsiran yang salah agar mampu menjadi teladan komunikasi

\section{DAFTAR PUSTAKA}

Bungin, Burhan. 2012. Metode Penelitian Kualitatif. Jakarta : Raja Grafindo Persada.

Husein Umar. 2009. Metode Penelitian untuk Skripsi Dan Tesis Bisnis. Edisi kedua. Jakarta : Rajagrafindo Persada.

Marwansyah. 2010. Manajemen Sumber Daya Manusia. Edisi Kedua. Bandung: Alfabeta.

Moloeng, Lexy J. 2013. Metode Penelitian Kualitatif. Bandung : PT Remaja Rosdakarya.

Robbins, Stephen P. 2003. Perilaku Organisasi. Index. Jakarta.
Susanto Eko Harry. 2010. Komunikasi Manusia : Esensi dan Aplikasi Dalam Dinamika Sosial Ekonomi Politik. Jakarta : Mitra Wacana Media

Undang-undang RI No.20 Tahun 2003 tentang Sisdiknas dan Peraturan Pemerintah Tahun 2010 tentang penyelenggaraan pendidikan serta Wajib Belajar 